JA: Jurnal Al-Wasath 3 No.1: 45-60

Journal homepage: https://journal.unusia.ac.id/index.php/alwasath/index

ISSN 2721-6160 (Online)

\title{
Rule of Law And Its Effect On Chinese Economic Development
}

\section{Roziqin}

Guanghua Law School, Zhejiang University, China

\begin{abstract}
China's economic growth during the Covid-19 pandemic was impressive because it did not fell into recession. China's government has become a role model for facing Covid-19 outbreaks. China is now the world's wealthiest country, if we see its Gross Domestic Product from Purchasing Power Parity (GDPPPP). China's position as the number one globally is faster than Jacques's prediction in 2009 that it will happen in 2050. For China, which does not implement liberal democracy, the writer hypothesizes that the reasonable choice to develop the economy is state-driven development through the rule of law. At present, the rule of law has become a daily conversation of the Chinese people. However, there are still many outsiders who doubt China has and applies the rule of law. It happens because China implements the rule of law with Chinese characteristics. This research will study the rule of law with Chinese characteristics, China's effort to implement the rule of law, and the rule of law on China's economy. This study uses a qualitative descriptive approach to explain the rule of law with Chinese characteristics. It will analyze the rule of law concept and its effect on China's economy. China applies the rule of law with Chinese characteristics based on Chinese traditions, which are heavily influenced by Confucius's teachings and prioritize obligations rather than rights. China has done many reforms action to implement the rule of law. The implementation of the rule of law in china makes China become a prosperous country now.
\end{abstract}

\section{Keywords:}

China, the rule of law, economy

\section{Roziqin}

Guanghua Law School, Zhejiang University, China

Email: 11902038@zju.edu.cn

(C) The Author(s) 2021

DOI: 10.47776 /alwasath.v2i1.166

\section{(c) (1)}

CC BY: This license allows reusers to distribute, remix, adapt, and build upon the material in any medium or format, so long as attribution is given to the creator. The license allows for commercial use.

\section{Classification \\ Conceptual Article}

Submitted: 11 April 2021

Accepted: 25 April 2021

Online: 25 April 2022 


\section{INTRODUCTION}

China's economic growth during the Covid-19 pandemic is impressive. Compared with other major countries that fall into recession, only China still had positive economic growth in 2020. China's GDP grew by $2.3 \%$ per year in 2020 . For the first time, the full-year GDP reached 100 trillion yuan (\$15.45 trillion). ${ }^{1}$ The World Bank predicted that China would have 6,9\% economic growth in 2021. ${ }^{2}$

China's government has become a role model for facing Covid-19 outbreaks. ${ }^{3}$ Moreover, before the Covid-19 pandemic, China's Gross Domestic Product (GDP) ${ }^{4}$ in 2019 was in the first rank globally when we use Purchasing Power Parity (PPP) exchange rate. ${ }^{5}$ It reached USD 23.460 trillion, ${ }^{6}$ which means China is now the world's wealthiest country. Even the United States of America (USA), which is being assumed as the most superpower country, apparently owes to China, reached USD 1.08 trillion as of March $2020 .^{7}$

The initiative of the Belt and Road Initiative shows how assertive China is today. By the end of January 2021, 140 countries have signed memoranda of understanding (MoU) with China to participate in the Belt and Road Initiative. Many countries and continents will be linked due to that project, and it is predicted will be the biggest project in the $21^{\text {st }}$ century. ${ }^{8}$ China's position as the number one globally is faster than Jacques's prediction in 2009 that it will happen in $2050 .{ }^{9}$

We can also know the Chinese people's welfare from their access to information technology. Even though many people think China is a closed country, China was the most internet user globally by 989 million in $2020 .{ }^{10}$ China is leading in $5 \mathrm{G}$ telecommunication technology while now pioneering 6G. ${ }^{11}$ Chinese people widely use online shopping and constantly break the world record from 11-11 (double eleven refer to online shopping on November 11, held by Alibaba Chinese). Before the Covid-19 outbreak, in 2019, its record was $\$ 38.4$ billion in 24 hours, which was more than half of what Amazon American company sold in an entire quarter. ${ }^{12}$

\footnotetext{
${ }^{1}$ CGTN, China's GDP grew 2.3 percent in 2020, the only major economy to see positive growth, Februari 28, 21, https://news.cgtn.com/news/2021-02-28/China-s-GDP-grew-2-3-percent-in-2020-Yf4Ie5dS12/index.html, accessed March 11, 2021

${ }^{2}$ World Bank. https://data.worldbank.org/, accessed March 14, 2021

${ }^{3}$ Ning, Y., Ren, R. \& Nkengurutse, G. China's model to combat the COVID-19 epidemic: a public health emergency governance approach. Glob health res policy 5, 34 (2020). https://doi.org/10.1186/s41256-020-00161-4.

${ }^{4}$ GDP is the sum of gross value added by all resident producers in the economy plus any product taxes and minus any subsidies not included in the value of the products (World Bank)

https://databank.worldbank.org/metadataglossary/jobs/series/NY.GDP.MKTP.KD.ZG

${ }^{5}$ Purchasing power parities (PPPs) are the rates of currency conversion that try to equalise the purchasing power of different currencies, by eliminating the differences in price levels between countries (OECD)

https://data.oecd.org/conversion/purchasing-power-parities-ppp.htm

${ }^{6}$ World Bank. https://data.worldbank.org/, accessed March 14, 2021

${ }^{7}$ The Balance.com, https:/www.thebalance.com/us-debt-to-china-how-much-does-it-own-3306355, accessed March $15,2021$.

${ }^{8}$ Countries of the Belt and Road Initiative (BRI), https://green-bri.org/countries-of-the-belt-and-road-initiative-bri/, accesed March 20, 2021.

${ }^{9}$ Martin Jacques, 2009, When China Rules the World: The Rise of the Middle Kingdom and the End of Western

World. England: Penguin Group., p. 3

${ }^{10}$ Cnbc.com, China says it now has nearly 1 billion internet users, February 4, 2021,

https://www.cnbc.com/2021/02/04/china-says-it-now-has-nearly-1-billion-internet-users.html, accessed March 15, 2021.

11 Cnbc.com. China starts development of $6 G$, having just turned on its $5 G$ mobile network. https://www.cnbc.com/2019/11/07/china-starts-6g-development-having-just-turned-on-its-5g-mobile-network.html, November 7, 2019, accesed March 15, 2021.

${ }^{12}$ Forbes.com. Alibaba's 11/11 Singles’ Day By The Numbers: A Record \$38 Billion Haul. https://www.forbes.com/sites/sergeiklebnikov/2019/11/11/alibabas-1111-singles-day-by-the-numbers-a-record-38billion-haul/\#7722f9fe2772, November 11, 2019, accesed March 15, 2021.
} 
Furthermore, the 2020 Fortune Global 500, a list of top 500 companies in the world, list includes 133 Chinese companies, including those from Hong Kong and Taiwan. China ranks first among the countries on the list, followed by the United States, which has 121 companies. ${ }^{13}$ For business in 2020, according to the World Bank, China is regarded as one of the most promising countries. ${ }^{14}$

The desire to make China the top country has been achieved. Under the Communist Party of China's (CPC) leadership, Xi Jinping, as the General Secretary of the Party, encourage the CPC members and all ethnic in China to pursue two centenary goals ${ }^{15}$ and make the Chinese Dream of rejuvenation of the Chinese nation come true.

The Chinese economy, which was once closed and weak, has changed dramatically for the 40s year. China also has experience facing a crisis and could lift the global economy out of recession due to the strong demand for various goods in $2009 .{ }^{16}$ Economic development usually uses two approaches, state-driven development, and market-driven development. For China, which does not implement liberal democracy, the writer hypothesizes that the reasonable choice to develop the economy is state-driven development through the rule of law. At present, the rule of law has become a daily conversation of the Chinese people. However, there are still many outsiders who doubt China has and applies the rule of law. It happens because China implements the rule of law with Chinese characteristics. Based on the above description, this research will study the following principal problems: 1) What is the rule of law with Chinese characteristics? 2) What is China's Effort to Implement Rule of Law? 3) What is the rule of law effect on China's economy?

\section{RESEARCH METHODS}

This study uses a qualitative descriptive approach to explain the rule of law with Chinese characteristics. It will analyze the rule of law concept and its effect on China's economy. This study uses secondary data from various books, journals, regulatory regulations, institutional reports, research, and the internet.

\section{DISCUSSION}

\section{Rule of Law With Chinese Characteristics}

The existence of law in China is not new. Since the Xia dynasty (2070 BC to $1600 \mathrm{BC}$ ), China society has recognized law, which was still in the form of ethics, as a social order. It was then accepted as the state norm. Every time the Chinese setback, there were always parties who want to adopt the western system in terms of politics and economics. For example, when the defeat of China in the opium war. However, this desire often was sunk by conservative power. ${ }^{17}$

During the revolution of 1911, a Government of the Republic of China with a nationalist pattern was formed, applied the Three Principles of the People and the theory of The Constitution of Five Powers advocated by Dr. Sun Ya-tsen. In 1911, China succeeded in finalizing the first Civil Code, which adopted German and Japanese laws and passed it in 1930. However, during the Mao Zedong period 1949-1976, China overturned all laws passed during the Nationalist

\footnotetext{
13 China Daily, 133 Chinese companies listed on Fortune Global 500, Agustus 11, 2020, https://www.chinadaily.com.cn/a/202008/11/WS5f324861a31083481725f9fe.html, accessed March 20, 2020.

${ }^{14}$ World Bank Group, 2020, Doing Business 2020: Comparing Business Regulations in 190 Economies, p. 1

15 The Two Centenary Goals are to complete the building of a moderately prosperous society in all respects by the centenary of the CPC (founded in 1921) and to build China into a modern socialist country that is prosperous, strong, democratic, culturally advanced, and harmonious by the centenary of the PRC. Those were put forth by the CPC at its 18th National Congress for building socialism with Chinese characteristics

${ }^{16}$ Hildebrandt, Tim. Will China Lift the World Economy Out of Recession?

https://www.internationalaffairshouse.org/will-china-lift-the-world-economy-out-of-recession/, July 31, 2020 , accessed March 20, 2020.

${ }^{17}$ Mo Zhang, op. Cit. p. 5 
Government, so that China was an era without law. At that time, China did not care about the law because it carried out the economy centrally and controlled its needs. At that time, all conflicts could be resolved through mediation or administrative means, regardless of people's rights and obligations. $^{18}$

That is because people are not familiar with the China rule of law. The rule of law was initially formed in a capitalist society based on a market economic system developed based on the Anglo-Saxon tradition. The rule of law was rooted in Great Britain's political and historical history and then was adopted in the United States of America and many countries. ${ }^{19}$

We have to notice that the law's existence is always based on the local community's social reality. Thus, to understand the rule of law, it is necessary to look at the context of China's social community. China applies the rule of law with Chinese characteristics based on Chinese traditions, which are heavily influenced by Confucius's teachings and prioritize obligations rather than rights. For the Chinese people, the government is their parent, who must be respected as trusting parents. The Trust Barometer survey from Edelman in 2019 confirms that 86\% of respondents trust in China's government. ${ }^{20}$

Besides, China is a socialist country. Experts emphasize that the rule of law in China is different from the individualistic West. The Socialist law system becomes one of the world's significant law systems besides civil law and common law. However, at that time, socialist law meant Soviet Law or Stalinist Law. ${ }^{21}$ Chinese law itself adopted many of the Soviet Laws before the open door. Still, after the open-door policy, many assumed it from the West apart from China's traditions and the Soviet Law.

\section{China's Effort to Implement Rule of Law}

Many people misunderstand Chinese law. That happens because many people think of a formal legal system should be like the Western kind. ${ }^{22}$ However, Chinese law has its characteristics. Each country has a history, and in China, it's essential. We have to consider that traditional Chinese law during the dynastic era was uninfluenced by the West. ${ }^{23}$ China has a phenomenally long, relatively continuous, and stable history compared to Western Europe's counterparts. This history can only influence legal developments, particularly the lawmaking system. ${ }^{24}$

At the time of the dynasty, every dynasty had its legal statutes enacted by the Emperor. It was called the "code." According to the name of the dynasty, each dynasty had its code, which would be called. The Great Ming Code, the Qing Code, or whatever, for example. Since the formal legal system was an integral part of the ruling apparatus of the Empire, the legal system would have disappeared in the early part of this century, when the Empire collapsed. ${ }^{25}$

The Qing dynasty, China's last imperial dynasty, end more than 3,000 years of imperial rule and ushering China into modernity. In the Qing Dynasty, China began to grapple with the need to seriously reform the legal system as part of its attempt to tackle modernity. However,

\footnotetext{
18 Jingjing Liu, "Overview of the Chinese Legal System," in China Update 1 (1), 2013, p. 1.

${ }^{19}$ Pietro Costa and Danilo Zolo, 2007, The Rule of Law: History, Theory, and Criticism. The Netherland: Springer, p. 3.

${ }^{20}$ Edelman Trust Barometer, 2019, p. 42.

${ }^{21}$ Mo Zhang, 2010, The Socialist Legal System With Chinese Characteristics: China's Discourse for the Rule of Law and A Bitter Experience, Temple Int' 1 \& Comp. LJ, p. 11

${ }^{22}$ William C Jones, 2003,Trying to Understand the Current Chinese Legal System. In C. Stephen Hsu (ed).

Understanding China's Legal System: Essays in Honor of Jerome A. Cohen. New York: New York University Press, p.7

${ }^{23}$ Ibid., p. 8

${ }^{24}$ Chuan Feng, Leyton P. Nelson, and Thomas W. Simon, 2016, China's Changing Legal System. Lawyers \& Judges

on Civil \& Criminal Law. DOI: 10.1057/9781137452061: Palgrave Macmillan., p. 11

25 Jones, op. cit., 7. 9. 
these early reforms could not gain a foothold in the Republican era's chaotic civil war conditions. $^{26}$

The Qing dynasty was overthrown in 1911 by Dr. Sun Yat-Hsinhai sen's revolution. Before the fall of imperial China, however, several attempts had been made to create a modern, democratic legal system. In 1898, for example, the Hundred Days' reform sought to change the existing imperial legal system. After only 104 days, the movement failed when Empress Dowager Cixi led a coup d'état against Emperor Guangxu, stopping his modernization attempt. Some of the changes that Emperor Guangxu had sought included the use of capitalism as well as manufacturing to bring China into the Industrial Age; the construction of a modern and robust army; the reform of the civil service examination system; the streamlining of bureaucracies to eliminate positions with little or no work; the end of the absolute monarchy and its replacement by a democratic constitutional monarchy; and moderation. In the end, the reform movement failed, but that failure helped push for the eventual fall of the Qing dynasty. ${ }^{27}$

The revolutionary forces that would overthrow the government in 1911 saw the conservative forces' resistance to political and legal reforms to confirm that the only way to bring about change was through a complete revolution. In 1902, another attempt was made to change the legal system. Succumbing to foreign pressures to modernize, the Chinese sought to reform their legal system by incorporating various parts of several countries' existing systems. While maintaining parts of the Grand Qing Codex, the Chinese Law Reform Commission has incorporated Japanese legal vocabulary and parts of the German Civil Code into the existing Chinese framework. The committee responsible for this reform consisted of two ministers responsible for legal review and consulted foreign legal experts. While considerable progress has been made in reforming the legal system, the fall of the Qing Dynasty ultimately prevented any of these changes from being implemented. ${ }^{28}$

The PRC was established in 1949. Mao rejected all remains of the Kuomintang's political, judicial, constitutional, civil law, and criminal law. In the early 1950s, the Communist Party of China adopted several regulations relating to marriage, land reform (initially promoting redistribution and subsequent collectivity), and corruption (CPC). From 1954 to 1956, when courts of justice were set up and schools of law were opened, the law flourished for a short time after the Constitution was approved. But the Anti-Rightist movement stopped these reforms abruptly.

After PRC's independence, the desire to realize the rule of law has existed since Mao Zedong's office. At the $30^{\text {th }}$ Meeting of the Central People's Government Committee, Mao stressed people to follow the Constitution after it had effective.

"...every citizen should follow it, especially the government personnel, including you (Note: the audience he addressed to). Those who do not (follow) will be deemed as opposing the Constitution. " 29

From August 1951 to June 1952, Mao launched the "Three-Anti Campaign." It consisted of anti-corruption, waste, and bureaucratism to clean corrupt government officials from corruption. In 1952 he also launched the "Five Anti-Campaign" (bribery, theft of state property, tax evasion, cheating on government contracts, and stealing state economic intelligence) ${ }^{30}$

However, during the great leap forward and the Cultural Revolution policy, China did not implement the law correctly. Without careful planning and the law, Mao changed the economic structure from agriculture to the industry through the great leap forward policy. He promised he would make China into the top ranks of the industrialized world. To make that dream came true,

\footnotetext{
${ }^{26}$ Peerenboom, op. cit., p. 1.

${ }^{27}$ Changwang and Nathan H. Madson, 2013, Inside China's Legal System. Cambridge: Oxford, p. 4

${ }^{28} \mathrm{Ibid}$.

${ }^{29}$ Quanxi, Wei, Feilong, op. cit., p. 91.

${ }^{30}$ Michael M Sheng. Mao Zedong and the Three-Anti Campaign (November 1951 to April 1952): A Revisionist Interpretation, Twentieth-Century China, 32 (1), 2006, 56-80, DOI: 10.1179/tcc.2006.32.1.56, p. 56.
} 
Mao instructed the party cadre to mobilize peasants to build roads, dams, terraced fields, and irrigation canals. ${ }^{31}$ That policy resulted in twenty million to thirty million deaths in 1958-1961, and the majority of Chinese people fell into poverty. ${ }^{32}$ Not much different, in the cultural revolution era between 1966-1976,

families were separated, careers upended, education interrupted, and striking political initiatives attempted amid a backdrop of chaos, new beginnings, and the settling of old scores. ${ }^{33}$

In the Cultural Revolution (1966-1987), law subsequently took a back seat to politics. ${ }^{34}$ At that time, the rule of right was killed and caused legal nihilism. During the decade-long Cultural Revolution, the entire system was almost disassembled: the Ministry of Justice was disbanded, law schools were closed, and the legal profession was eliminated (Chang and Madson, 5). ${ }^{35}$ Throughout the PRC's Mao era, the legal system was used to control the population, remove 'counterrevolutionaries' and promote socialism. The CPC utilized the legal system and the law to give it legitimacy and achieve party goals. The criminal justice system relied very little on justice and concentrated more on developing the class struggle. ${ }^{36}$

After Mao's passed away, there was a change in the government's focus for economic development with an open door policy, so it needed legal action. China changed its economy to a socialist market gradually. In 1978, Deng Xiaoping, as Mao's successor, announced he would make legal policies to promote China after it experienced poverty as a result of the Cultural Revolution (1966-1976). ${ }^{37}$ Deng hoped that the law would become a reference for all activities and be carried out correctly and that every violation would be punished.

The existence of the legal system in China has been started effectively under the leadership of Deng Xiaoping. After Deng came to office, legal development became an essential means of realizing a socialist market system that turned China into a world economic power. Not long after the reform era, NPC issued Criminal Law and Civil Law. Started from 1989, citizens have an equal position with the government due to their ability to sue the government after China passed the Administrative Litigation Law. ${ }^{38}$

China has changed from an agricultural economy to industry, from a planned economy to a market economy. Deng opened the door of China for economic relations with other countries. With Deng's leadership, this drastic economic change occurred without political turmoil. One sure thing is that after Mao, economic changes have been preceded by legal changes.

Deng Xiaoping's rule (1978-1992) is an incredible increase in activity enacted with over 2,000 laws since Mao's death in 1976. This frenzy of legal activity has not only been unrelenting but also increasingly occurred. ${ }^{39}$ Legal reforms and the rule of law again became a hot issue. ${ }^{40}$ It is almost impossible to open any Chinese newspaper nowadays without seeing any reference to the rule of law. In the countryside, signs painted on buildings proclaim the need to act following legislation. Flyers posted in cities urge passersby to uphold the law steadfastly. Many scholars have produced thousands of books and articles on the subject literally. And the Constitution was amended in 1999 to provide for the creation of a socialist rule-of-law state explicitly. ${ }^{41}$

\footnotetext{
${ }^{31}$ Ropp, Paul S. 2010. China in World History. New York: Oxford University Press, p. 140.

${ }^{32}$ Richard Curt Kraus, 2012, The Cultural Revolution: A Very Short Introduction, New York: Oxford University Press, p. 8.

${ }^{33}$ ibid

${ }^{34}$ Peerenboom, op. cit. p. 1.

${ }^{35}$ Changwang and Madson, op. cit, p. 5

${ }^{36}$ Changwang and Madson, op. cit., p. 59.

${ }^{37}$ Mo op. cit, p. 3

${ }^{38}$ Quanxi, Wei, Feilong, op. cit. p. 129

${ }^{39}$ Chuan, Nelson, Simon, op. cit., p. 10

${ }^{40}$ Peerenboom, op. cit. p. 1

${ }^{41}$ Ibid. 
To advance the economy, China carried out many economic reforms, including provided incentives to farmers to produce crops and sell them freely on the market. China also decentralized economic policies, especially in the field of trade. That has caused many trade policies issued by the Regional Government to encourage fair competition between regions. China was also removing barriers regulation to promote the flow of foreign investment.

In 1993, China confirmed changes to the economic system by entering the words socialist market economy in its Constitution. China's government believes that rule of law can guarantee stability to attract investment both from within and outside the country. The rule of law also ensures that people receive fair treatment in carrying out economic activities to develop appropriately. ${ }^{42}$ Changes in the Chinese economy began with changing the rule of man to the rule of law. Through the 1999 constitutional amendment, China included the rule of law as one of the constitutional parts.

After the open-door policy, China becomes one of the countries which have huge markets over the world. Since 2001, China becomes a member of the World Trade Organization (WTO), so that it is subject to WTO provisions related to the principle of market opening and nondiscrimination. However, some leaders blamed the open-door policy, and China's entry into the WTO made corruption widespread. ${ }^{43}$ Corruption cases increased due to many public officials' opportunities to abuse power for private gain. Before the open-door policy, the common corruptions were guanxi (connection) and zhouhoumen ("back-door" practices). The decentralization after the open-door policy also contributed to increasing corruption due to the greater power of regional officials. ${ }^{44}$ Meanwhile, government officials' salaries were paltry compared with society due to their 'fast-growing rapidly. ${ }^{45}$

Corruption becomes the main problem in China, which puts the public and the government in contradiction. ${ }^{46}$ Many people associated the company from China with the most corrupt when doing their business abroad. ${ }^{47}$

In the Maoist era, corruption numbers were not unknown. While reform came to China, corruption increased rapidly. Since 1982, Chinese leaders have worried that corruption was critical and continues to a large sum. Criminal economic crime cases filing increased tremendously, going from 9,000 in 1980, the year China's first Criminal Code was established, to 28,000 in 1985, and nearly doubling again in 1986, when the Communist Party launched its second anti-corruption drive. The 1989 anti-corruption campaign resulted in a high number of criminal cases, numbering over a hundred thousand. Throughout the 1990s, the number of lawsuits filed against government officials gradually decreased, but corruption steadily increased. The number of senior officials in 1990 nearly tripled, while 1995 more than doubled the number of such officials. The regime began to remove more than 2,500 senior officials each year. The size of bribes increased significantly over time, rising from $\$ 4,000$ in 1984 to $\$ 140,000$ in 1998 , then tripling from 1998 to $\$ 273,000$ in $2005 .{ }^{48}$ Even in Lai Xiaomin's case, bribery reached almost 1.79 billion yuan ( $\$ 276.7$ million). He had been accused of soliciting in bribes over ten years, a period when he was chairman of one of China's "big four" state-controlled asset management

\footnotetext{
${ }^{42}$ Doyle, David. Rule of Law: The Backbone of Economic Growth, Oxford Union, July 17, 2014.

${ }^{43}$ Daniel Davis. 2008. Hu Jintao. New York: Chelsea House Publishing, p. 63

${ }^{44}$ Jon S.T Quah. Minimizing Corruption in China is This An Impossible Dream?, Contemporary Asian Studies

Series, 9 (38), 2014, p. 16

${ }^{45}$ Ibid., p. 47

${ }^{46}$ Asian Development Bank, 2005, Knowledge, Commitment, Action Against Corruption in Asia and The Pacific, Papers Presented at the $5^{\text {th }}$ Regional Anti-Corruption Initiative for Asia and the Pacific. Beijing, p.78.

${ }^{47}$ Cambridge University Press, 2009, Global Corruption Report 2009: Corruption and the Private Sector. New York, xxix

${ }^{48}$ Wedeman, Andrew. 2012. Double Paradox Rapid: Growth and Rising Corruption in China. New York: Cornell University Press, p. 2 
firms, China Huarong Asset Management Co. It made the Chinese court sentenced him to death in 2021. ${ }^{49}$

Corruption is almost a top urgent problem confronting the country based on a survey. ${ }^{50} \mathrm{At}$ the $18^{\text {th }}$ session of the Standing Committee of the Tenth National People's Congress, China also had ratified the UNCAC on October 27, 2005. Furthermore, China has reformed its financial and investment system and seriously dealt with corruption cases to promote integrity and justice, strengthening citizen participation in fighting corruption. ${ }^{51}$ China also has reformed its StateOwned Enterprises (SOE).

China is also active in the United Nations Office on Drugs and Crime (UNODC), in which corruption is one of the institution's concerns. On October 17, 2019, China and UNODC signed a memorandum of cooperation in combating corruption. ${ }^{52}$ On May 15, 2018, China also signed a new joint plan of action to enhance strategic partnership in crime prevention and criminal justice. $^{53}$

Continuing the previous anti-corruption campaign from his predecessor, President Xi Jinping launched an extensive anti-corruption campaign at the $18^{\text {th }}$ National Congress of the CPC, November 8, 2012. ${ }^{54}$ When he gave a speech at the first group study session of the Political Bureau of the $18^{\text {th }}$ CPC Central Committee on November 17, 2012, he warned all Party members to enhance their ability to resist corruption and ward off corruption risk. In the Third Plenary Session of the $18^{\text {th }}$ CPC Central Committee, $\mathrm{Xi}$ also strengthened the Party's unified leadership to build a clean and honest government and combat corruption. Xi reminded the Party that fighting corruption is a long-term project, hoping to carry out the campaign until the end. ${ }^{55}$ According to $\mathrm{Xi}$, combating corruption, upholding integrity, and improving party conduct are critical for the Party and the state's survival. ${ }^{56}$

In the Third Plenary Session of the $18^{\text {th }}$ CPC Central Committee, November 9, 2013, Xi stressed some corruption problems, including anti-corruption forces synergy and the accountability system. ${ }^{57} \mathrm{Xi}$ then launched Anti-Corruption campaign as a part of China's economic reform to avoid inefficiencies that may bring bankruptcy. ${ }^{58}$

$\mathrm{Xi}$ is targeting lowly bureaucrats and influential leaders or often called flies and tigers. From January 1, 2010, until July 2018, at least 2,447 officials, from flies and tigers, were sentenced for corruption, ${ }^{59}$ including former Politburo Standing Committee member Zhou Yongkang. Under Xi Jinping's term's office, there is no exception in fighting corruption. Xi does not consider whether the perpetrators are civilian or military, ordinary people, or party officials. It

\footnotetext{
49 The Guardian, https:/www.theguardian.com/world/2021/jan/05/china-sentences-top-banker-to-death-forcorruption-and-bigamy, January 5, 2021, accessed March 3, 2021

${ }^{50}$ Manion, Melani. 2004. Corruption By Design: Building Clean Government in Mainland China and Hongkong. Harvard University Press, p. 85-86.

${ }^{51}$ Asian Development Bank, op. cit, p. 35

${ }^{52}$ UNODC, Report on the meeting of the Open-ended Intergovernmental Working Group on the Prevention of Corruption held, in Vienna from 4 to September 6, 2019

${ }^{53}$ UNODC. China to strengthen crime prevention, criminal justice cooperation through new joint action plan. https://www.unodc.org/unodc/en/press/releases/2018/May/unodc--china-to-strengthen-crime-prevention--criminaljustice-cooperation-through-new-joint-action-plan.html accessed March 20, 2020

${ }_{54}$ Peng Wang, The Chinese Mafia: Organized Crime, Corruption, and Extra-Legal Protection, Oxford University Press, 2017, p. 188.

${ }^{55}$ Xi Jinping (a), Decision of the Central Committee of the Communist Party of China on Some Major Issues Concerning Comprehensively Continuing the Reform. Explanatory notes made to the Third Plenary Session of the 18 th CPC Central Committee. November 9, 2013

${ }^{56}$ Xi Jinping (b), Historical Wisdom Helps Us Combat Corruption and Uphold Integrity April 19, 2013

${ }^{57}$ Xi Jinping (a), op. cit.

${ }^{58}$ Sinaga, Lidya Christin. 2013. Six Decades of Indonesia-China Relations: An Indonesian Perspective. LIPISpringer, p. 20.

${ }^{59}$ China File, https://www.chinafile.com/infographics/visualizing-chinas-anti-corruption-campaign, accessed September 19, 2010
} 
broke the unwritten rule "xing bu shang dafu" or humiliating high-ranking officials by legal punishment. ${ }^{60}$

In 2017, the NPC strengthened its spirit to fight against corruption through the constitution amendment. To uphold a zero-tolerance policy on corruption, in 2018, NPC also established a new supervisory organ, namely The National Supervisory Commission, and mention it in the Constitution. The Commission is the highest supervisory organ in China and exercises supervisory power independently, including in anti-corruption. It cooperates and mutually checks with adjudicatory and procuratorial organs and law enforcement departments. ${ }^{61}$ The Commission strengthens the Party's capacity to combat corruption. It integrates fighting corruption with a single anti-corruption agency, which previously had been done by two institutions with the dualtrack system. Those commissions are the Commission for Discipline Inspection (CDI), the Party's organ, and the People's Procuratorate, a state organ. ${ }^{62}$

To combat corruption, the Chinese government has made various efforts. Some of them enact the sunshine policy, ${ }^{63}$ enacting some anti-corruption regulations, giving heavy penalties for the corruptor - from low to high-level officials, implementing shuanggui. ${ }^{64}$ Due to many protests on shuanggui, at the $19^{\text {th }} \mathrm{CPC}$ Congress in Beijing on October 18, 2017, President Xi said shuanggui would be replaced by liuzhi, new detention broader reforms to the legal system. ${ }^{65}$

China also uses human flesh search engines to expose government officials' committed corruption. ${ }^{66}$ The government also supported institutions that play a role in eradicating corruption and enforcing the death penalty for corruptors. ${ }^{67}$ In 2001, The CPC Centre Committee reestablished the Leading Group for National Informatization and urged for e-governance implementation to promote open and clean government. China is now more transparent in civil servant recruitment, and promotion after The Standing Committee of the National People's Congress passed the Civil Service Law in 2005. It has also issued some regulations and codes of conduct for civil servants, including the prohibition of seeking illegal benefits from their power or receiving gifts or attending dinners with conflict of interest. ${ }^{68}$

Chinese leaders have implemented far-reaching administrative reforms that enhance their leaders' transparency and encourage government involvement. These reforms include adopting the Open Government Information (OGI) Regulations following local open government experiments, encouraging public participation in the governance of legislation and administration, and integrating citizens' satisfaction surveys into criteria used to evaluate government officials' performance. For example, open government legislation allows individuals to request government information and instructs government agencies at various levels to disclose information that is of major public interest, such as government budget and expenditure information. The central government also raises public awareness through online comments as well as the holding of

\footnotetext{
${ }^{60}$ Peng Wang, op. cit., p. 189.

${ }^{61}$ China Constitution, Article 127

${ }^{62} \mathrm{Li} \mathrm{Li}$ and Peng Wang. From Institutional Interaction to Institutional Integration: The National Supervisory Commission and China's New Anti-corruption Model. SOAS University of London. 2019 DOI:10.1017/S0305741019000596, p. 3

${ }^{63}$ Sunshine policy is a policy that government require all of their officials to declare their major personal matters, like building or purchasing of housing, sending children to study abroad, wedding ceremonies of their children, that make it transparent to the public (china.org)

${ }^{64}$ Shuanggui is an intra-party disciplinary practice that requires a CPC member under investigation to cooperate with questioning at a designated place and a designated time. The practice is exercised by the Party's disciplinary officials (Xinhuanet)

${ }^{65}$ Xinuanet. China to scrap "shuanggui" practice: Xi, October 18, 2017. http://www.xinhuanet.com//english/201710/18/c 136688679.htm. Accessed March 21, 2021

${ }^{66}$ Zhifang Yu. 2018. Human Flesh Search and Privacy Protection: Two Case Studies From China. Tilburg University, p. 6.

${ }^{67}$ Jiangnan Zhu. Do Severe Penalties Deter Corruption? A Game-Theoretic Analysis of the Chinese Case. The China Review, 12 (2), 2012, p. 2

${ }^{68}$ Asian Development Bank, op. cit., p. 30

53
} 
public hearings. On the National People's Congress and the Council of State websites, all draft laws and regulations are available. ${ }^{69}$

For example, when it comes to transparency, the Supreme People's Court earlier this year began releasing all civil, administrative, criminal, and commercial case records - a decision that applied not just to the high court but all of China's 3,000-plus subnational courts. The Xi administration has also taken steps to disclose information on all transactions completed on Chinese soil since the 1990s and other data related to the leadership's biography, corporate ownership, and government spending. Despite limited participation, China's State Council has begun soliciting public opinion on the NPC's agenda, providing citizens with an opportunity to participate in the agenda-setting process. The Party's fourth plenum, convened in early 2014, highlighted public consultation as a critical pillar of governance and put legal and judicial reform on a top-tier agenda. ${ }^{70}$

\section{The Rule of Law Effect on China's Economy}

With Chinese characteristics, the state's creation and maintaining a supportive growth climate are vital to emerge markets to achieve economic miracles. ${ }^{71}$ With the control carried out, China developed two goals: to advance various existing companies while still paying attention to national interests. In a socialist climate, the formation of regulations that lead to markets will differ from those used in the West because it has a more communitarian approach than individual characteristics.

The choice of the word "socialist market economy" in the Chinese Constitution means that the state and the private sector go hand in hand in developing the economy. That causes the government to act as a market regulator and a market actor. The Socialist market economy, based on socialism, makes the system different from the capitalist market economy. Some call China implementing state capitalism, as opposed to western capitalism, which is too individualistic. Option for the state capitalism was not separated from China's history, which has a very long experience in the imperial system, and only brief experience shaped republic and the knowledge of the planned economy to a market system. ${ }^{72}$ That history differs the rule of law in China from that in the West. In China, the rule of law with Chinese characteristics is set for society's stability and a better economy. ${ }^{73}$

China's state capitalism's success seems to imply that other countries should be looking to emulate it in which market mechanisms are permitted to take place, but government subsidies and regulations constrain them. SOEs are allowed to participate in the market, but private firms are allowed to devour state-controlled resources, promoting growth and environmental sustainability. ${ }^{74}$

Although China has liberalized trade with its state capitalism, it continues to support SOE. However, the significant state role made some SOEs is ineffective due to political intervention. On the other side, the reformed SOE is mostly influenced by politicians who have many objectives. ${ }^{75}$ Based on WTO studies, in China, more than one in every four state enterprises

\footnotetext{
${ }^{69}$ Jonathan R Stromseth, et. al. China’s Governance Puzzle Enabling Transparency and Participation in a SingleParty State. Cambridge: Cambridge University Press. 2017, p. 3

${ }^{70}$ Ibid., p. 23

${ }^{71}$ Jingchen Zhao, Promoting a More Efficient Corporate Governance Model in Emerging Markets Through Corporate Law, 15 Washington University Global Studies Law Review. 447 (2016), p. 458.

${ }^{72}$ Li Xing and Timothy M Shaw. The Political Economy of Chinese State Capitalism. JCIR 1 (1), 2013, p. 95

73 Katrin Blasek, 2015, Rule of Law in China: a Comparative Approach. London: Springer, p. 16.

74 Juann H. Hung, Yang Chen (ed), 2018, The State of China's State Capitalism, Evidence of Its Successes and Pitfalls, Singapore: Palgrave Macmillan.

${ }^{75}$ Yusuf, Sahid, Kaoru Nabeshima, Dwight H Perkins. 2006. Under New Ownership: Privatizing China's StateOwned Enterprises. Washington: The World Bank, p. 90-91.
} 
makes a loss. ${ }^{76}$ The SOE pampering policy became a policy that went back to the 1970 s when SOE ran around $75 \%$ of the industry with targets set by the government. That causes the market not to develop due to economic distortion. ${ }^{77}$ To that end, the Chinese government needs to improve SOE Governance and not over-indulge them with various facilities and preferences.

By open-door policy implementation supported by the rule of law, China has gone through three economic transformations, from centralized planning to market-oriented, closed to open, and from an agrarian to a manufacturing power to a middle- or long-latitude country of the world. During these transformations, 660 million people have been lifted above the World Bank poverty line of $\$ 1.25$ per day by exchanging goods and services, human capital, technology, and knowledge. In other words: China's rapid growth has helped lift hundreds of millions of people out of poverty and even changed their ethnic identities during the last three decades of remarkable expansion. ${ }^{78}$

Investors like laws that guarantee transparency. ${ }^{79}$ Based on Chinese Prime Minister Li Keqiang's report in 2018, China has carried out various reform agendas and used World Bank indicators regarding business ease. For example, China is making significant progress in improving construction permits, which initially needed about 38 procedures in 400 days, become 20 procedures in 200 days. ${ }^{80}$ China also increases transparency in electricity costs.

China also does a reform reducing expropriation risks, and improving creditors' rights led to increased firm value. China, especially in Beijing and Shanghai, also increased investor minority by imposing liabilities on controlling shareholders for unfair-related party transactions and clarifying ownership and control structures. China also reformed the taxation field. In 2006, businesses in Shanghai needed an average of 832 hours per year to prepare, report, and pay taxes, and there were 37 payments. While in 2020 , the business is only 138 hours per year and seven tax payments. ${ }^{81}$

With various advances, based on data from the United Nations Conference on Trade and Development (UNCTAD), in 2019, China became the second-largest recipient of Foreign Direct Investment (FDI) in the world after the United States with a value of 140 billion U.S. Dollars. ${ }^{82}$ It turns out that China has not stopped reforming itself. The National People's Congress (the NPC) of China approved the Foreign Investment Law (FIL) in 2019. FIL became a fundamental law of China in foreign investment. It united and replaced the three existing laws on foreign investment in China (i.e., the Law on Sino-Foreign Equity Joint Ventures (EJV Law), the Law on SinoForeign Contractual Joint Ventures (CJV Law), and the Law on Wholly Foreign Owned Enterprises). FIL reiterates that China implements high-level foreign investment liberalization, facilitation policies and establishes and improves foreign investment mechanisms. It also creates a stable, transparent, and predictable market environment where all domestic and foreign competitors will be treated fairly. ${ }^{83}$

\footnotetext{
76 The World Bank and Development Research Center of the State Council of the People's Republic of China, China 2030: Building A Modern, Harmonious, and Creative Society, The World Bank, 2013

${ }^{77}$ Congressional Research Services. China's Economic Rise: History, Trends, Challenges, and Implications for the United States. 2019, p. 2.

${ }^{78}$ Xiaolin Wang, Limin Wang, and Yan Wang, 2014, The Quality of Growth and Poverty Reduction in China, Heidelberg: Springer, ix

${ }^{79}$ Bui Ngoc Son, Law and Development Theory: A Adilogical Engagement, The Geo Wash. Int' 1 Rev, Vol 51, 2019, p. 87

${ }^{80}$ World Bank Group, 2020. Doing Business 2020: Comparing Business Regulations in 190 Economies, p. 10

${ }^{81}$ Ibid., p. 51.

${ }^{82}$ Xinhuanet. China remains second largest FDI recipient in 2019:

UNCTAD http://www.xinhuanet.com/english/2020-

01/21/c_138721848.htm\#: :text=FDI\%20inflows\%20to\%20China\%20remained,attracted\%20251\%20billion\%20U.S . 20dollars. , accessed October 12, 2020

${ }^{83}$ King \& Wood Mallesons, Into A New Era: Changes and Challenges in the Legal Regime for Foreign Investment in China, March 18, 2019
} 


\section{CONCLUSION AND RECOMENDATION}

Since the Xia dynasty (2070 BC to 1600 BC), China society has recognized law, which was still in the form of ethics, as a social order. The rule of law in China is based on Chinese traditions that prioritize obligations rather than rights and are mostly based on Confucius's teachings. For the Chinese people, the government is their parent, who must be respected as trusting parents. The Trust Barometer survey from Edelman in 2019 confirms that $86 \%$ of respondents trust in China's government. Experts emphasize that the rule of law in the West is different from the individualistic West.

After PRC's independence, the desire to realize the rule of law has existed since Mao Zedong's office. Mao launched the "Three-Anti Campaign" to clean corrupt government officials from corruption. After Mao passed away, China is implementing an open-door policy for economic relations with other countries, requiring legal improvement to uphold legal certainty. It is almost impossible to open any Chinese newspaper nowadays without seeing any reference to the law. China's government believes that rule of law can guarantee stability to attract investment.

In China, the rule of law with Chinese characteristics is set for society's stability and a better economy. It also supports a growth climate to achieve economic miracles. By open-door policy implementation supported by the rule of law, China has gone through three economic transformations, from centralized planning to market-oriented, closed to open, and from an agrarian to a manufacturing power to a middle- or long-latitude country of the world. With its open-door policy system supported by the rule of law, now China becomes a rich country.

\section{REFERENCE}

\section{Legal Documents}

People's Republic of China Constitution

Black Law Dictionary, $8^{\text {th }}$ ed, 2004

Blasek, Katrin. 2015. Rule of Law in China: a Comparative Approach. London: Springer.

Cambridge University Press. 2009. Global Corruption Report 2009: Corruption and the Private Sector. New York.

Castellucci, Ignazio. 2012. Rule of Law and Legal Complexity in the People's Republic of China, Trento: University of Degli Studies in Trento.

Changwang and Nathan H. Madson. 2013. Inside China's Legal System. Cambridge: Oxford

Chuan Feng, Leyton P. Nelson, and Thomas W. Simon. 2016. China's Changing Legal System. Lawyers \& Judges on Civil \& Criminal Law. DOI: 10.1057/9781137452061: Palgrave Macmillan.

Congressional Research Services. 2019. China's Economic Rise: History, Trends, Challenges, and Implications for the United States.

Costa, Pietro, and Danilo Zolo. 2007. The Rule of Law: History, Theory, and Criticism. The Netherland: Springer.

Davis, Daniel. 2008. Hu Jintao. New York: Chelsea House Publishing.

Jacques, Martin. 2009. When China Rules the World: The Rise of the Middle Kingdom and the End of Western World. England: Penguin Group.

Juann H. Hung, Yang Chen (ed), 2018, The State of China's State Capitalism, Evidence of Its Successes and Pitfalls, Singapore: Palgrave Macmillan. 
William C Jones. 2003. Trying to Understand the Current Chinese Legal System. In C. Stephen Hsu (ed). Understanding China's Legal System: Essays in Honor of Jerome A. Cohen. New York: New York University Press.

Kraus, Richard Curt. 2012. The Cultural Revolution: A Very Short Introduction. New York: Oxford University Press.

$\mathrm{Li} \mathrm{Li}$ and Peng Wang. From Institutional Interaction to Institutional Integration: The National Supervisory Commission and China's New Anti-corruption Model. SOAS University of London. 2019. DOI:10.1017/S0305741019000596

Manion, Melani. 2004. Corruption By Design: Building Clean Government in Mainland China and Hongkong. Harvard University Press.

Mo Zhang. 2010. The Socialist Legal System With Chinese Characteristics: China's Discourse for the Rule of Law and A Bitter Experience, Temple Int' 1 \& Comp. L.J.

Peerenboom, Randall. 2002. China's Long March Toward Rule of Law. Cambridge: Cambridge University Press,

Peng Wang, The Chinese Mafia: Organized Crime, Corruption, and Extra-Legal Protection, Oxford University Press, 2017.

Quanxi Gao, Wei Zhang, Feilong Tian. 2015. The Road to the Rule of Law in Modern China. Beijing: Springer.

Ropp, Paul S. 2010. China in World History. New York: Oxford University Press.

Stromseth, Jonathan R, et al. China's Governance Puzzle Enabling Transparency and Participation in a Single-Party State. Cambridge: Cambridge University Press. 2017.

Sinaga, Lidya Christin. 2013. Six Decades of Indonesia-China Relations: An Indonesian Perspective. LIPI-Springer.

The World Bank and Development Research Center of the State Council of the People's Republic of China, China 2030: Building A Modern, Harmonious, and Creative Society, The World Bank, 2013

Woo, Margaret Y. K. 2000. "Law and Discretion in Contemporary Chinese Courts," in The Limits of the Rule of Law in China. Washington: University of Washington Press.

World Bank. 2003. Combating Corruption in Indonesia: Enhancing Accountability for Development. World Bank.

World Bank Group, 2020. Doing Business 2020: Comparing Business Regulations in 190 Economies.

Xi Jinping. "Decision of the Central Committee of the Communist Party of China on Some Major Issues Concerning Comprehensively Continuing the Reform: Explanatory notes made to the Third Plenary Session of the 18th CPC Central Committee". November 9, 2013. In Xi Jinping. 2014. The Governance of China. Beijing: Foreign Languages Press.

Xi Jinping. "Historical Wisdom Helps Us Combat Corruption and Uphold Integrity," April 19, 2013. In Xi Jinping. 2014. The Governance of China. Beijing: Foreign Languages Press.

Xiaolin Wang, Limin Wang, and Yan Wang. 2014. The Quality of Growth and Poverty Reduction in China. Heidelberg: Springer.

Yusuf, Sahid, Kaoru Nabeshima, Dwight H Perkins. 2006. Under New Ownership: Privatizing China's State-Owned Enterprises. Washington: The World Bank.

Asian Development Bank. 2005. Knowledge, Commitment, Action Against Corruption in Asia and The Pacific, Papers Presented at the $5^{\text {th }}$ Regional Anti-Corruption Initiative for Asia and the Pacific. Beijing. 
Bui Ngoc Son, Law and Development Theory: A Adilogical Engagement, The Geo Wash. Int' 1 Rev, Vol 51, 2019.

Edelman Trust Barometer, 2019.

Jiangnan Zhu. Do Severe Penalties Deter Corruption? A Game-Theoretic Analysis of the Chinese Case. The China Review, 12 (2), 2012, p. 1-32.

Jingchen Zhao, Promoting a More Efficient Corporate Governance Model in Emerging Markets Through Corporate Law, Washington University Global Studies Law Review. 447 (2016).

Jingjing Liu, "Overview of the Chinese Legal System," in China Update 1 (1), 2013

David Doyle. 2014, July 17. Rule of Law: The Backbone of Economic Growth, Oxford Union.

King \& Wood Mallesons, Into A New Era: Changes and Challenges in the Legal Regime for Foreign Investment in China, March 18, 2019.

Li Xing and Timothy M Shaw. The Political Economy of Chinese State Capitalism. JCIR 1 (1), 2013.

Ning, Y., Ren, R. \& Nkengurutse, G. China's model to combat the COVID-19 epidemic: a public health emergency governance approach. Glob health res policy 5, 34 (2020). https://doi.org/10.1186/s41256-020-00161-4.

UNODC. Report on the meeting of the Open-ended Intergovernmental Working Group on the Prevention of Corruption, held in Vienna from 4 to September 6, 2019.

Sheng, Michael M. Mao Zedong and the Three-Anti Campaign (November 1951 to April 1952): A Revisionist Interpretation, Twentieth-Century China, 32 (1), 2006, 56-80, DOI: 10.1179/tcc.2006.32.1.56

Zhifang Yu. 2018. Human Flesh Search and Privacy Protection: Two Case Studies From China. MA Thesis in Tilburg University.

CGTN, China's GDP grew 2.3 percent in 2020, the only major economy to see positive growth, February 28, 21, https://news.cgtn.com/news/2021-02-28/China-s-GDP-grew-2-3-percentin-2020-Yf4Ie5dS12/index.html, accessed March 11, 2021.

Cnbc.com. China starts development of $6 G$, having just turned on its $5 G$ mobile network. https://www.cnbc.com/2019/11/07/china-starts-6g-development-having-just-turned-on-its5g-mobile-network.html, November 7, 2019, accessed March 15, 2021.

Cnbc.com, China says it now has nearly 1 billion internet users, February 4, 2021, https://www.cnbc.com/2021/02/04/china-says-it-now-has-nearly-1-billion-internetusers.html, accessed March 15, 2021

Forbes.com. Alibaba's 11/11 Singles' Day By The Numbers: A Record \$38 Billion Haul. November 11, 2019, https://www.forbes.com/sites/sergeiklebnikov/2019/11/11/alibabas1111-singles-day-by-the-numbers-a-record-38-billion-haul/\#7722f9fe2772, accessed March $15,2021$.

Hildebrandt, Tim. Will China Lift the World Economy Out of Recession? https://www.internationalaffairshouse.org/will-china-lift-the-world-economy-out-ofrecession/, July 31, 2020, accessed March 20, 2021.

The Balance.com, https://www.thebalance.com/us-debt-to-china-how-much-does-it-own3306355, accessed March 15, 2021.

The Guardian, https://www.theguardian.com/world/2021/jan/05/china-sentences-top-banker-todeath-for-corruption-and-bigamy, January 5, 2021, accessed March 3, 2021.

World Bank. https://data.worldbank.org/, accessed March 14, 2021. 
Xinhuanet. China to scrap "shuanggui" practice: Xi, October 18, 2017. http://www.xinhuanet.com//english/2017-10/18/c_136688679.htm. Accessed March 21, 2021.

Xinhuanet. China remains second largest FDI recipient in 2019: UNCTAD http://www.xinhuanet.com/english/202001/21/c_138721848.htm\#: :text=FDI\%20inflows\%20to\%20China\%20remained,attracted\% 20251\%20billion\%20U.S. \% 20dollars. , accessed March 21, 2020. 


\section{Competing interests}

No conflict interest.

\section{Funding.}

None.

\section{Acknowledgements.}

Thank you to all those who have supported and helped this research.

\section{About the Authors}

The authors is a student at Guanghua Law School, Zhejiang University, China 